\title{
Geopolitics as Palimpsest: Contextual Inscriptions of the Global War on Terror
}

Political Geography 55 (2016) 30-39, 10.1016/j.polgeo.2016.05.001

\section{Felix CiUtă}

UCL, Gower Street, London, WC1E 6BT, UK; f.ciuta@ucl.ac.uk

\begin{abstract}
$\underline{\text { Abstract }}$
This article aims to develop the agenda of a grounded, contextual critical geopolitics, with particular emphasis on the interaction between local and hegemonic geopolitics. This is achieved by examining the local reception of the geopolitics of the 'global war on terror' (GWOT) in the context of the establishment of US bases on Romanian territory following the 2004 US Global Posture Review. A close reading of this context reveals a complex and ambiguous relationship, simultaneously assertive and subversive, between the GWOT's sui generis, territorially non-specific geopolitics of transit, and Romania's exceptionalist geopolitics of place, significance, and convergence. Not only did the GWOT geopolitics fail to erase local geopolitics, but it also became muddied, contaminated, and inadvertently destroyed by the 'old' local geopolitical knowledge. This suggests an understanding of geopolitics as a palimpsest, the product of serial, imperfect, synchronic and diachronic erasures and writings-over that produce geopolitical knowledge of, and in different contexts. In broader conceptual terms, this study highlights the heteroglossia of geopolitical knowledge, the resilience of local geopolitics, and the importance of contextual sensitivity in the pursuit of the normative mission of critical geopolitics.
\end{abstract}

Keywords: geopolitics; palimpsest; heteroglossia; Romania; US bases; Global War on Terror

\section{INTRODUCTION}

Despite arguments that it was only an epiphenomenon, rather than a fundamental shift in world politics (Kennedy-Pipe and Rengger, 2006), the politics and ethics of the global war on terror (GWOT) have been etched in the practices of international politics as well as in the daily routines of contemporary life (Amoore, 2009). In addition, both the nature and the effects of the geopolitics of the GWOT are still highly contested, primarily due to the fragmented conceptual landscape of its analysis, and the absence of detailed empirical data that truly reflects its global nature. On the first count, critical interpretations of the geopolitics of the GWOT must still reconcile its unprecedented combination of 
scale, ideology and transformative intent (Dalby 2009) with its imagined geographies that evoke familiar hegemonic geopolitical projects (Dalby 2007; Gregory, 1995; Kearns 2006). On the second count, questions also remain about the operation, transmission and reception of the GWOT in places other than its ideological epicentre and military theatres (Bialasiewicz et al., 2007; Coleman, 2003; Dalby, 2003; Gregory 2004; Ryan, 2011).

In this context, the task of this article is twofold: to examine the inscription of the GWOT in a previously ignored local context, and through this, to further elaborate the conceptual and normative parameters of a contextual, grounded critical geopolitics along the lines initially formulated in the pages of this journal (Ó Tuathail, 2010). Indeed, it was in analyses of the GWOT that the calls for grounding critical geopolitics emerged, starting from a recognition of the 'inherently contested nature of the geographies at the heart of the war on terror', which are continually remade as 'people invariably find ways to reimagine and contest them, albeit in different ways and to different extents' (Ingram and Dodds, 2009: 11). This paper will illustrate precisely such a reimagination and contestation through the grounding of critical geopolitics in the context of the establishment in Romania of US bases following the 2004 US Global Posture Review (GPR). While the need to examine 'the geopolitical imagination of the War on Terror from non-Western [sources]' (Sharp 2011: 297) has already been recognised, Romania is an intriguing addition to the roster of studies of the local geopolitics of the GWOT.

First, the context of Romania attests the ambiguity of geopolitical knowledge positions suggested by the reference to the 'non-Western' in this last statement. Given its current membership of NATO and the EU, it is easy to forget that Romania's membership campaign - as that of other East European states - was phrased for an entire decade in terms of its 'return to Europe' and becoming (like) the 'West' (Ciută, 2007; also Kuus, 2007). Second, this story stands in stark contrast to other accounts of the base politics of the GWOT. The US bases were received in Romania with widespread approval across the political establishment and public opinion, rather than with resistance (Davis, 2011) or the violent collusion of local elites (Oza, 2007; Sidaway, 2010; Vine, 2009; Woon, 2011). Using a qualitative methodology combining elements of critical discourse analysis, process-tracing interviews with foreign policy officials in Washington and Bucharest, and a decade-long survey of Romanian printed mass media, I will argue that this overt embrace masks a complex relationship - historical, conceptual and moral - between the hegemonic geopolitics of the GWOT and the geopolitics locally inscribed. This simultaneously contradictory and mutually-supportive coexistence shows that local geopolitics not only 
bears the indelible marks of past (hegemonic) geopolitics, but can also leave its own traces on the hegemonic scripts of the present.

I begin my argument with a discussion of the conceptual and normative dimensions of grounded critical geopolitics, with the aim of fleshing out the understanding of geopolitics as a palimpsest. The characteristics of the geopolitics of the GWOT and GPR are discussed in the next section, followed by a sketch of the policy context of its reception in Romania. The fourth section provides a reading of Romanian geopolitics, while in the final section I analyse this paradoxical intersection of geopolitical knowledge. In the conclusion, I will map the implications for the conceptual and normative agenda of grounded critical geopolitics.

\section{GEOPOLITICS AS PALIMPSEST: HETEROGLOSSIA AND SUBVERSION}

For grounded critical geopolitics, contextualization is, as Geertz would put it, the name of the game (2000: xi). ${ }^{1}$ To be sure, contextual perspectives are far from homogenous in epistemological and normative terms (Ciută, 2009), and have already been incorporated in feminist, postcolonial or ethnographic approaches in political geography, as well as more specifically in the literature on subaltern geopolitics (Sidaway, 2012; Sharp, 2011, 2013). However, in critical geopolitics the need for accentuated 'grounding' emerged from a very specific concern with the relationship between what Agnew (2007) has called 'geographies of knowledge'. It is also here that the need for conceptual and normative disambiguation arises.

While noting the homogenizing and simplifying nature of the geopolitics of the GWOT (2010: 256), Ó Tuathail also observed that some of its denunciations have manifested a similar 'tendency to flatten geopolitical practices and homogenize geopolitical discourses rather than appreciate their cultural thickness, contested articulations and unstable heteroglossia' (2008: 342). 'Grounding' was thus the antidote to these failures of geopolitical thinking, enabling both the epistemological task of critical geopolitics to delineate 'the circulation of ideas among places $[\ldots]$ and investigate in empirical detail how this actually plays out' (Kuus, 2013: 33), and its emancipatory mission to unmask and undo the effects of hegemonic discourses and practices (Dahlman and Ó Tuathail, 2005: 645).

Epistemologically, the localizing impulse of critical geopolitics is best captured in its heightened sensitivity to the heteroglossia of geopolitical discourses and knowledge.

Originally, Bakhtin used the concept of heteroglossia to draw attention to the importance of context, which 'can refract, add to, or, in some cases, even subtract from the amount and kind of meaning the utterance may be said to have when it is conceived only as a systematic 
manifestation independent of context' (Bakhtin, 1981: xx). Heteroglossia signals, in other words, not only that different actors can assign different meanings to a particular discourse which is shown to be inherently polysemic, and not only that a discourse can achieve different meanings in different contexts. Equally importantly, heteroglossia also brings into focus the constant, but often neglected multiplicity of voices that speak in any one particular discourse. Applied to our case study, this is to say that the geopolitical / ideological discourse of the GWOT is stratified, fragmented, and 'destroyed' (cf. Morris, 1994: 16) through, and into multiple local 'groundings'.

While earlier references in political geography took heteroglossia to reflect 'the power of place and the transcendence of geography' (Folch-Serra, 1990: 268), grounded critical geopolitics prioritises a heteroglossic approach also for its emphasis on the role of power, hierarchy and their contestation as ubiquitous ingredients of every discursive encounter. This is all the more significant when it comes to the analysis of the geopolitical discourses of (and about) hegemonic powers. As suggested by Ó Tuathail, in this sense heteroglossia enables a detailed grasp of the 'disjunctures and contradictions in the relationship between the grounded local and the foreign policy discourse and practices of the major powers' (2010: 263).

As the last statement suggests, hegemony and heteroglossia are locked in a complex relationship that requires contextualization, as Bakhtin argued at length in his work. This is far from a trivial point in critical geopolitics, where authors such as Agnew have suggested that the effect of hegemonic geopolitical thinking is to draw 'elites (and populations) [to] accept and even laud ideas and practices about world politics and their place in it that they import from more powerful countries' (Agnew, 2007: 145, emphases added). In this formulation - closely aligned with the Marcusean perspective on the tendency of the oppressed to 'identify [...] with the existence which is imposed upon them and have in it their own development and satisfaction' (Marcuse, 1964: 13) - practices of import clearly entail a unidirectional circulation and monoglossic understanding of geopolitical knowledge.

In contrast, echoing Said's call to 'take account of both $[\ldots]$ imperialism and resistance to it' (1994: 66), Ó Tuathail pointed out precisely that the practices of 'import' deplored by Agnew are heteroglossic, given that 'localized conditions, structures and power struggles mediate and subvert international interventionist practices' (Ó Tuathail, 2010: 263, emphasis added). In this reading, heteroglossia is inherently subversive, which makes it a constitutive part of the normative imperative of contextual sensitivity, which Kuus describes as 'central to destabilizing hegemonic knowledge' (2013: 33). The upshot of the dual 
commitment to heteroglossia and subversion is therefore that grounded critical geopolitics appears in all its forms - localized, subaltern, marginal - as an analytical perspective precommitted to 'the moral authority of the view from below' (Sharp, 2011: 304). However, subversion also happens from somewhere, and thus it too must be grounded in critical geopolitical analysis, as must be its moral authority. As Ingram and Dodds very aptly observed, the war on terror is not inscribed 'across some kind of geopolitical tabula rasa but across landscapes that bear the marks of pre-existing and multiple struggles over enduring colonial, Cold War and other geopolitical orders' (2009: 7).

Understanding geopolitics as a palimpsest best captures such serial, imperfect, synchronic and diachronic erasures and writings-over that produce geopolitical knowledge of, and in different contexts. Initially deployed in studies of cultural landscapes, the metaphor of the palimpsest is inherently heteroglossic: its definition - a manuscript on which successive texts are written, each of them partly erased to make room for the next connotes the 'multilayered structure that emphasizes the coexistence of multiple visions and impacts of different cultures' (Mitin, 2010: 2111). In addition, a palimpsestic view also denotes the intrinsic historicity of geopolitics. Since a palimpsest not only provides the material support for, but also is the 'succession' of texts that produce it, to see geopolitics as palimpsest encourages us to see 'the histories in the everyday world, to look for the traces of the biography of places' (Crang, 1996: 442). Notably, among committed contextualist geographers, Massey was somewhat sceptical of expressing heteroglossia through the form/metaphor of the palimpsest, for it suggested the notion of the 'colonial text as writing over a thereby obliterated other' (Massey, 2005: 110). However, my interpretation of a geopolitical palimpsest see local geopolitics as 'a kind of indelible ink of the palimpsest that cannot be fully erased' (Braun, 2007-8: 2). In other words, it is in the nature of palimpsests never to be fully erased, because 'the dense juxtaposition, repetitions, and weight of multiple mythologies, reduces the power of any single original story to dictate the form of the final palimpsest produced' (14). A geopolitical palimpsest is therefore the quintessential way in which the local 'consistently in one way or another reasserts itself' (Massey, 2005: 88).

From this conceptual vantage point, the case of Romania provides a useful opportunity to elicit the historical context and heteroglossic character of the encounter between local and hegemonic geopolitics, as well as the normatively 'ambiguous position of [local] actors in relation to hegemonic practices' (Kuus, 2013: 30). Paraphrasing Genette, what we can see in the Romanian context is 'how a myth can, with a little help, "read another"' (Genette, 1997: 399). While its sheer magnitude makes it tempting to generalise the irresistible and destructive impact of the geopolitical template implemented through 
the GPR (Vine, 2012), the study of the Romanian context shows an authentic fusion of geopolitical horizons in which Romania's (self) inscription in the matrix of the GWOT was enabled by, and performed through, recitations of its own locally sedimented geopolitics. Despite the imperative tenor in which the GWOT flatly abolished the particularity of place, the presence of the US bases was signified by the Romanian elites in a register that rewarded Romania's entrenched geopolitical identity. Rather than mere import or obliteration, the result was an imperfect writing of the geopolitics of the GWOT on the local geopolitical palimpsest. Not only did the GWOT geopolitics fail to erase the local, but it also became muddied, contaminated, and inadvertently destroyed by the 'old' local geopolitical knowledge. Hegemonic 'writing' and local 'import' were accompanied by an unexpected kind of resistance that took place in the name of a series of earlier 'imported' (written-over) and similarly heteroglossic hegemonic geopolitics. But before delving into the Romanian context, the GWOT's own geopolitics must be charted.

\section{THE BASE-GEOPOLITICS OF THE GWOT}

The logistical structure of the GWOT emerged almost entirely from a single quantum of strategic planning, the 2004 US Department of Defence GPR. The GPR was a blueprint for the reconfiguration of the military presence of the US to address the challenges of fighting the distant battles of the war on terror, encompassing 'a cross-section of relationships, activities, facilities, legal arrangements, and global sourcing and surge', elements designed to support 'security cooperation efforts and $[\ldots]$ enable prompt global military action' (US DoD, 2004a: 7).

Central to the GPR was a triad of new basing concepts which reflected the need for a military presence that was global, networked and free from local political constraints. Its 'tiered power-projection deployment scheme' (Noonan, 2004: 2) consisted of Main Operating Bases (MOB) with permanently stationed combat forces and robust infrastructure; Forward Operating Sites (FOS), expandable facilities with limited military personnel and prepositioned equipment, designed primarily for bilateral and regional training; and Cooperative Security Locations (CSL), facilities with little or no permanent presence whose purpose was primarily to 'provide contingency access and be a focal point for security cooperation activities' (US DoD, 2004a: 10). A pivotal role in this network was played by the new types of bases, the small and austere FOS / CSL which became known in English-speaking policy and media circles as 'lily-pads', a designation first used by former SACEUR General James L. Jones (Anderson, 2003; Combat Films, 2005). In line with the political vision of the GWOT, lily-pads had to fulfil three conditions: be located in places 
where troops were 'wanted, welcomed, and needed'; be located in environments where 'flexible legal and support arrangements' were in place; and be in the proximity of potential crisis points, allowing rapid, preferably instant deployment (Rumsfeld, 2004b: 3).

Hailed as the 'most profound re-ordering of U.S. military forces overseas' since World War II, the GPR was deliberately transformative (US DoD, 2004a: 2; for a more sceptical view, see O'Hanlon, 2008: 9). The new base structure envisaged by the GPR was seen as 'not merely a derivative of strategy [but] a driver in its own right' (OBC, 2005: 6), and as a consequence, it appeared from the start 'inescapably, indeed overwhelmingly, political in terms of its effect on the rest of the world' (Bloomfield, 2006: 49). As one of its key architects argued, there was 'not going to be a place in the world where it's going to be the same as it used to be' (Douglas J. Feith, quoted in Campbell and Johnson Ward, 2003: 95). Through its emphasis on maximising access, speed, and impact, the GPR thus was not only the logistical vehicle the GWOT (Rumsfeld, 2004a, b; US Senate, 2004: 93), but was also intrinsic to defining the features of its geopolitics: novelty, territorial non-specificity, and transit.

For its architects, the GPR was a testament of 'ingenuity, innovation, and progress' (Rumsfeld, 2004a). Although Bush administration officials stressed that the posture review was not determined 'by transient considerations of current events' (Douglas J. Feith, in Schrader, 2003: 2), this was not meant to suggest a disconnect between the GPR and the GWOT, but to assert the sui generis nature and transformational power of the geopolitics of the GWOT itself. Since the GWOT was seen to be caused by exceptional events which required exceptional measures, its geopolitics had no historical traces in both a political sense - past experience was irrelevant - and in conceptual terms, for it was not legitimated by, or cast in the mould of any established lineage of geopolitical thought (pace Kearns, 2006). The new basing strategy envisioned a 'global force management system' (US DoD, 2004a: 8) that moved 'away from [...] threat -based' towards 'capability-based' military planning (OBC, 2005: 2) in order to cope with 'uncertainty' as the defining condition of the global environment (US DoD, 2004a: 5-6). In addition, the GPR was simultaneously moving away from the geographical specification of potential threats to US security (Critchlow, 2005: 4), signalling a second distinctive characteristic of the GWOT geopolitics.

Although small in scale by design, the combined effect of the envisaged network of lily-pads was meant to be, in terms of spatial coverage and political ingress, nothing less than total. The GPR was key to the successful prosecution of the GWOT precisely because it created the ability to act 'on a global basis - across theatres' (US DoD, 2004a: 8). All the situational assessments and responses for which the GPR laid the logistical foundation 
were going to be 'from the standpoint of the world and not just of a region' (US DoD, 2004b: 6). In essence, this meant that the GWOT's was a territorially non-specific geopolitics: its drive for total global access operated a 'respatialization of the globe' (Ingram, 2009: 257) which rendered all particular locations - customarily the central object of classical geopolitics - insignificant in themselves. Lily-pads enabled 'flexibility and speed of response to anywhere' (Critchlow, 2005: 8, emphasis added). In the spatial economy of the GWOT, the value of lily-pads was thus derived from the totality to which they gave access, rather than their geopolitical specificity. This created a paradoxical spatial disassociation in which location lost its intrinsic significance, while its new value in the currency of the GWOT was established as a function of the spatial totality of the globe to which it could facilitate access.

This relates to the third distinctive characteristic: the GPR entrenched a geopolitics of transit. The GPR's governing principle was that of 'military access' (US DoD, 2004a: 4), which combined the ambition of global coverage with freedom from any local constraints (Bloomfield, 2006: 57; Henry, 2006: 42). The network geometry of the GPR bypassed regional segregation altogether, aiming to facilitate military action 'both within and across various regions of the world', and more specifically to enable power projection across 'seams' (US DoD, 2004a: 9; Garamone, 2004a, 2004b; Isenberg, 2004: 2). Yet as mentioned above, in this geopolitical logic it was not the lily-pads as such that mattered: what mattered was that the military units stationed in them could 'jump from country to country on a moment's notice' (Schrader, 2003: 3), allowing the deployment of US forces 'wherever and whenever they are needed' (US DoD, 2004a: 15). Instead of the fixed architecture of past imperial geopolitics where military bases enabled primarily the control of the space of their location, the network geography of the GPR was designed to ensure 'flow [...] into, through, and from' theatres of operations (US DoD, 2004a: 9). As '[platforms] from which to send U.S. troops elsewhere' (Schrader, 2003: 3, emphasis added), the lily-pads were always meant to facilitate transit, rather than presence, as had long been the case with the US troops stationed in postWW2 Europe, for example.

From this reading, it could be argued that the GPR did indeed envisage a 'transformation of territories in the metropolitan imagination' (Said, 1994: 21) through an indiscriminate enfolding of all regions into a single political-logistical space which '[stripped] margins of their context' (Kuus, 2013: 33). But as will be shown in the next sections, the superimposition of this geopolitical framework on the context where lily-pads were to be established elicited a local reading that was different yet not new, contradictory yet not subversive, autochthonous yet residually hegemonic. 


\section{THE GWOT IN CONTEXT: POLICY REALIGNMENTS IN ROMANIA}

Even though the establishment of the lily-pads was given special significance in Romania, it cannot be considered in isolation from other policies locally adopted in the context of the war on terror. Official statements never reproduced the momentarily infamous comment of a local editorialist that 9/11 constituted an 'excellent opportunity', but the Romanian political elite was quick to understand that all its foreign policy objectives would be affected. In addition to the 2005 agreement to host the lily-pads, the marks of the GWOT can be identified in three other major areas: NATO membership; the 2002 Bilateral Immunity Agreement (BIA) with the US; and in Romania's 2007 National Security Strategy.

In 2001, Romania was yet to achieve its two long-standing objectives of joining NATO and the EU, so its reading of the consequences of $9 / 11$ was initially entirely subsumed to these goals. NATO membership in particular had to be re-packaged in the vernacular of the GWOT, because the principles of enlargement, formulated in the mid-90s, were incongruous with the 'coalitions of the will' required by Donald Rumsfeld's new vision for international cooperation. As a result, the Romanian government gradually shifted its argument for membership to emphasise the ability to contribute to the fight against terrorism. The Parliament's decision, adopted on 19 September 2001 with only one abstention, stipulated that Romania would act 'as a de facto NATO ally', participating with NATO member states in actions to 'combat international terrorism $[\ldots]$ including through military means', and would allow, at NATO's request, the use of 'all facilities on Romanian air, land, and maritime territory in support of counter-terrorist operations' (RParl, 2001). This also led to the strong support Romania offered to the US decision to invade Iraq in 2003 (Vilnius 10, 2003), and to the Romanian government's collusion with the US programme of 'extraordinary rendition'. Although vehemently denied by the Romanian government (BBC Ro, 2007), its involvement was cited in the reports of the Council of Europe and the EU Parliament (PACE, 2006a: 19-20; PACE, 2006b; PACE, 2007; EP, 2007), and was recently acknowledged by Romanian politicians at the highest level (Actmedia, 2015).

Directly related to the establishment of the lily-pads was the signing on 1 August 2002 of a Bilateral Immunity Agreement (BIA, or 'Article 98' Agreement), designed to prevent the prosecution of American citizens by the International Criminal Court (ICC, 1998: 69). Evidently, the BIA was intrinsically linked to the context of the GWOT. As one of its key architects indicated, the US had urged 'doctrinal and legislative changes in allied 
capitals consistent with the practical realities of the war on terrorism' (Bloomfield, 2006: 61; $62)$, and BIAs were a pivotal element in the US effort to 'institutionalize the GWOT domestically and internationally' (US JCS, 2006: 19). Between 2002 and 2005 the US government conducted an intensive campaign which led to the signing of over 100 BIAs.

Romania was the first European state to sign such an agreement (and one of the very few to do so) even though the EU had asked the candidate states to not sign BIAs until it formulated a common position (CEU, 2002). Although not ratified by the Romanian parliament (Mediafax, 2008), the treaty was considered 'a striking act of Realpolitik' (Brucan, 2005: 3) that clearly put the bilateral relationship with the US at the top of Romania's foreign policy agenda (Moldovan et al., 2009: 12; PACE, 2007: 27).

A longer term impact of the GWOT could be seen in the 2007 National Security Strategy (NSSR). To a certain extent, the glaring influence of the GWOT on the NSSR is unsurprising. Earlier documents of this type had also provided readings of the international context that were favourable to the main vectors of Romania's security policy, rendering its choices necessary and inevitable. Consequently, the tropes of the GWOT pervaded the Strategy, its authors explicitly seeking to formulate a document that would 'legitimate the participation of national forces to the global war against terrorism' (NSSR, 2007: 24). Thus, the Romanian government adopted unreservedly the doctrine of preemptive war advocated by the US (White House, 2002) - itself met with much criticism, both domestically and internationally - as a necessary and legitimate stance in the fight against terrorism. Although eliminated from the final version, the first draft also included references to another voguish, but no less controversial trope of the GWOT, stipulating that 'Romania will participate to actions of coalitions of the will, according to [...] the principle of the right to individual and collective self-defence' (DNSSR, 2006: 12-13).

Most of the local media reaction noted that Romania lacked the capabilities to pursue a true doctrine of pre-emptive war, and that the cloning of the US position was likely to make Romania a target of terrorist attacks (Stan, 2007: 3; IPP, 2005: 59; Institutul PRO, 2006: 3). Notably, a representative of the then opposition (SDP) also claimed in a parliamentary debate that such conspicuous alignment with the US security philosophy meant that Romania's 'national security strategy is suffused with a neoconservative view of the world and Romanian society, [which] makes possible the establishment of an authoritarian political regime' (Stan, 2007: 3; also IOŞ, 2006: 16). The reference to the ideological underpinnings of the GWOT was all the more striking given that SDP had led the government that had signed the Romanian-US BIA in 2002, when then-President Ion Iliescu (also SDP) declared that Romania and the US had 'identical positions on the way to 
address the great challenges that the international community is facing, including the threat of terrorism' (cited in PACE, 2007: 28). In contrast, the NSSR was seen to undermine Romania's international identity, because by '[borrowing] from the American version its missionary vocation', Romania would appear to 'position itself as a regional power with a civilizing role in the Black Sea region' (IOŞ, 2006: 16).

While these critiques alluded to the subversive effects of the GWOT, they neither had a significant political impact, nor were they explicitly connected to Romania's participation in the global base structure proposed in the GPR. It was this policy that fully integrated Romania in the geopolitical template of the GWOT, and at the same time, provided a prominent stage for the assertion of its own geopolitical identity.

\section{A PALIMPSEST FOR THE GWOT}

In the run-up to the official launch of the GPR, Pentagon officials had been sounding out partners around the world to identify potential sites for the new lily-pads (Anderson, 2003; BBC, 2003; Fuller, 2003; US DoD, 2003), and Romania offered to host bases from the early stages of these consultations (Moldovan et al., 2009: 11). Following several high-level meetings (Ziua, 2005) and three years of expert-level negotiations (Moldovan et al., 2009: 15-16), the deal was signed on December $6^{\text {th }} 2005$ and ratified by the Romanian Parliament on July $6^{\text {th }} 2006$, establishing the use by US forces of four facilities of various sizes and purposes (RParl, 2006a; b, RMFA, 2005).

News of the successful negotiation of the US presence in Romania was immediately sloganised in both media and official reaction, led by then-foreign minister Mihai Răzvan Ungureanu's proclamation 'The Americans are coming!' (Munteanu, 2005; Orescu, 2005). In direct reference to one of the defining elements of Romania's post-communist folklore (Lefter, 2005), according to which Romanians had been 'waiting for the Americans to arrive' since the end of World War II, the lily-pads were seen as nothing less than the fulfilment of a national 'dream' and 'ancient expectation' (RParl, 2007). Parliamentary grandiloquence aside, there can be little doubt that the significance of the bases stretched well beyond the mere augmentation of Romania's military capability, because the number of US troops stationed in Romania was capped at 3000, with limited equipment and rotated for training purposes. Although the cap was lifted in April 2015 by decision of the Romanian Parliament (Diac, 2015), the bases have never been used to full capacity, much to the disappointment of the Romanian hosts (Coon, 2008; Moldovan et al., 2009). As of June 2015, the US had a total of 620 troops deployed in Romania (Pantazi and Cozmei, 2015). 
Yet contrary to what one might expect in the case of such a significant policy, Romanian officials did relatively little to explain its rationale (Moldovan et al., 2009: 12-14). Despite being hailed as a 'national issue' for Romania, neither the consultations announced in 2003 (US DoD, 2003), nor the joint session of the two houses of the Romanian Parliament which subsequently approved the stationing of US troops on Romanian territory (RParl, 2007), shed too much light on the precise reasons why the Romanian government took this decision. The Ministry of Foreign Affairs press communiqué ran through a list of positive effects of the basing agreement which included 'strengthening Romania's strategic profile, $[\ldots]$ the consolidation of national security, increased interoperability with US and other allied armies, and increasing Romania's attractiveness for foreign business and capital' (RMFA, 2005). The national security dimension stretched beyond the war on terror to include Romania's long-standing concern with Russia's influence (Popa, 2005: 34), and the related issues of energy security and security institutionalisation in the Black Sea region, both high on Romania's foreign policy agenda at the time (Băsescu, 2005: 4; RParl, 2007: 3). Other official positions contained similarly generic references to 'facilitating cooperation' with the United States (ISN, 2005) or to 'diplomatic and economic gains' (BBC, 2005; Sullivan 2006) - the latter, always likely to be minor given the size and limited activity of the bases (GMF, 2005), and proving very slow (if at all) to materialize (Martinescu, 2009).

As head of the US negotiating team Ambassador Robert Loftis averred (personal interview), the message coming from the Romanian establishment was that the US military presence was simply a good in itself. It should be surprising therefore that the bases did not cause any controversy, either in the Romanian political establishment - the agreement was ratified unanimously, while the law approving the stationing of US troops was adopted with only one vote against - or in the wider public, where the presence of American bases enjoyed a high level of approval (IPP, 2005: 74-77). However, this seemingly whimsical enthusiasm becomes comprehensible if seen in the context of the Romania's geopolitical mythology. From that vantage point, the decision appears driven by what was perceived in Romanian policy circles as a perfect match between the requirements of the GPR and the geopolitical offer of Romania. Romania was presented as the ideal lily-pad, satisfying all the three conditions of the GPR stipulated above: willing, flexible, and conveniently located. But this was more than a case of Romania fitting the lily-pad profile like the proverbial glove: the GPR itself appeared as a geopolitical vision that finally grasped Romania's significance. 
In other words, this was neither a case of hegemonic geopolitics being written on a blank manuscript, nor one in which it erased the local geopolitical script. Rather, the implementation of the GWOT was made possible by the geopolitical knowledge already scripted locally. Understanding the localization of the GWOT requires therefore an understanding of Romania's own geopolitical culture.

\section{No Place Like Home: Romania's Exceptionalist Geopolitics}

It is indeed possible to identify a distinctly Romanian geopolitics, whose contours continue to be drawn in political, media, academic and popular discourse. Like all geopolitical cultures (Ó Tuathail, 2004), Romania's is also smelted from a combination of sedimented national memories, a militarized reading of geography, and circumstantial interest. Early Romanian geopolitical thought was intrinsically related to the formation of the Romanian state and the territorial repercussions of the two world wars. Its central principles, 'unity' and 'continuity', were both essential for authenticating the spatial, ethnic, geographic, and economic coherence of the Romanian state, as well as the historical permanence of the Romanian people in the 'natural' areal defined by its borders (for recent treatments, see Bowd and Clayton, 2015, Cioculescu 2009; for more extensive histories of Romanian geopolitical thought, see Cotoi, 2000, esp. 180-207; Didă, 2010a, b; Dobrescu, 2003, esp. 25-36; Posea, 1994; Săgeată, 2011; Simileanu and Săgeată, 2009). These themes are now taken for granted in Romanian geopolitics, whose contemporary inflections are tuned in to the requirements of other foreign policy issues, from energy security to the Black Sea region (Ciută, 2008) and the after-effects of the ongoing Crimean crisis. ${ }^{2}$

Significantly for the purpose of our argument, Romanian geopolitics is the product of often contradictory interpretations and appropriations of 'other' geopolitical ideas from Ancel, de Martonne, Ratzel, Kjellen, and Haushoffer in the early years (Bowd and Clayton, 2015) to Mackinder, Kissinger and Brzezinski more recently (Nazare, 2005; Pintescu, 2005). From the perspective of grounded critical geopolitics, there are two issues that stand out here. First, this signals that the geopolitics of the GWOT found in Romania a geopolitics already characterised by heteroglossia, distilled from multiple strands of earlier hegemonic geopolitics. Second, the study of this context produces a 'view from below' that challenges the normative assumptions of critical geopolitics: on the one hand, it can be considered locally 'authentic', yet on the other, it contains obvious historical traces of hegemonic geopolitics.

While its defining characteristics are not necessarily unique, uniqueness defines Romania's geopolitical identity, which is built on a series of remarkable singularities: 
uncommon location, exceptional 'geostrategic' worth, perennial political significance, and a long history as a geopolitical object combined with chronic attempts at establishing its own geopolitical subjectivity. Romania's unique location is undoubtedly the central trope in these geopolitical discourses. In global terms, Romania is seen as the place, and therefore all serious geopolitical projects need this place. Assertions of geopolitical exceptionalism are of course far from unique (Jones and Clark, 2012; Kuus, 2007) - even if both the meaning of exceptionalism, and its sources, are often imprecise and vary considerably - and also never isolated from the domestic dimension of base politics (Calder, 2007; Cooley, 2005; Cooley, 2007; Warf, 1997; Woodward, 2004). But in this particular geopolitics, exceptional location is matched by exceptional significance. Even before Romania was actually 'Romania', historical political figure I.C. Brătianu was advocating the significance of the Romanian Principalities as 'the key to the Orient' (cited in Stoicescu, 2008: 152), foreshadowing both the logic of classical geopolitics as we know it today, and its most well-known dictum, Mackinder's 'who rules Eastern Europe commands [...] the world' (Mackinder, 1919:186). In similar vein, former president Iliescu contended in 2003 - the year preceding Romania's accession to NATO, and the launch of the GPR - that Romania's 'role as "pivot" (plaque tournante) in intra-and extra-European relations' was essential for understanding its 'geostrategic utility' (Iliescu, 2003: 27).

The third defining characteristic is that Romania's is a geopolitics of convergence. Romania, former president Iliescu was again arguing in 1994, 'is not only in the Centre of Europe, but in the centre of Central Europe' (Iliescu, 1994). An array of spatial metaphors accompanies all accounts of Romania's history and geopolitics: axes and crossroads, bridges and corridors, they all lead to Romania; even buffers and barriers are buffers and barriers because fluxes - of empires, trade, energy or logistics - inexorably converge towards it (for a detailed discussion, see Stoicescu, 2008: 141-239). It was the fate of Romania - the story goes - to simultaneously separate imperial ambitions, and to unite Europe (Iliescu, 1994). This was seen to be particularly relevant in the security environment of post-Cold War Europe, where Romania was seen to be at 'the crossing point of geopolitical and strategic axes [and] the knot which coherently closes the regional security network' (Constantinescu, 1997: 6), an 'outpost of a logical strategic system, bridging the Baltic sea to the Black Sea, branching out to the Caspian Sea and the Adriatic Sea' (Pleşu, 1998: 4), and a 'bridge between civilisations and different economic and cultural interests' (NSSR, 2007: 18).

To be sure, the accuracy or compatibility of these spatial metaphors is open to discussion, and Romania is not the only palimpsest on which we can find heteroglossic traces of multiple hegemonic geopolitical narratives (Bassin and Aksenov, 2006). Yet the 
strength of sedimented local geopolitical knowledges rarely lies in their accuracy, but in their ability to glue together disparate national memories and hybrid voices, establishing the 'blissful clarity' (Barthes, 1973: 143) through which unfamiliar worlds and events are translated into the familiar and inevitable. Against assumptions of the extirpative power of hegemonic geopolitics, it should thus be unsurprising that Romania's reception of the GPR was conditioned by its own deeply sedimented geopolitics. But in stark contrast to the other local contexts mentioned at the start, here the GPR was read as a validation of Romania's geopolitical identity. And yet, as will be shown in the next section, this reading was profoundly contradictory, working against the defining features of the geopolitics of the GWOT, and simultaneously against Romania's own geopolitics.

\section{GROUNDED GEOPOLITICS: COMPLIANCE, RESISTANCE, DISSONANCE}

Key to understanding the localization of hegemonic geopolitics in this case is not just the fact that the geopolitics of the GWOT was different from Romania's geopolitical mythology. The sui generis, territorially non-specific, transit geopolitics of the GWOT stands indeed in high contrast with Romania's exceptionalist geopolitics of place, significance, and convergence, and the fundamental differences between the strategies and geographic scales used by Romania and the US were explicitly acknowledged by Romanian officials (Strategikon, 2006: 20). What is equally significant about their encounter is the manner in which, paraphrasing Genette again, one has been read through the other. Seen from Romania, the GWOT looked different, its geopolitics appropriated and translated through the local geopolitical vernacular. The local reception of the GPR activated both the sedimented tropes of Romania's geopolitical identity, and the heteroglossic reflex that created them. The result was a spectacular negation of the geopolitical principles carried by the GPR, negation made even more striking by the fact that it came in the course of a manifestly wholehearted embrace.

To begin with, contact with the Romanian context effectively abolished the original geopolitical solipsism of the GPR. Contrary to its intended philosophy, the GWOT was read locally not as a fundamental geopolitical shift, but rather, as a sort of return to normality the normality of a familiar geopolitical logic. In this logic, the bases were seen to demonstrate the traditional - in historical, as well as geopolitical terms - interest of the US (not only of Romania) in the 'Eurasian Rimland' (Popa, 2005: 27), as well as the fact that 'the role of the military and geographic location [was] increasing' (Paşcu, 2002). 'Location' was indeed the dominant trope in the Romanian narrative regarding the US bases, aided by the extolment of Romania's 'favourable geographic position' by American officials 
(Condoleezza Rice, in Perescu, 2005). Indeed, most of the media and political commentary seemed to agree that 'the basic attraction of Romania as a new base of operations for US forces is geographic' (Shimkus, 2006: 5).

However, by abrogating the uniqueness of the geopolitics of the GWOT, its local reading also resignified 'location' diametrically. 'Places, not bases' was the principle epitomising the geographically anti-specific and politically noncommittal nature of the GPR (US Senate, 2004: 28). Originally, this axiom was designed to signal the need to overcome the constraints of, and what was perceived as an over-attachment to the old (MOB) format of US bases such as those from Japan and Germany. As argued in the second section, attachment to 'place' signified attachment to a global panorama in which the primary criterion for the selection of base sites was access, not location. For this, the GPR had placed from the outset 'a premium on developing more flexible legal and support arrangements with our allies and partners where we might choose to locate, to deploy, or to exercise our troops' (US Senate, 2004: 9). The US had made clear that 'host countries that would impose nettlesome constraints on the out-of-country deployability of U.S. forces should not expect to be significant hubs in the new American defense posture' (Bloomfield, 2006: 57). Troops were to be deployed only 'in a place where people agree with what you're doing, so they don't shut down ports and they don't shut down airfields' (Schrader, 2003: 2). During the US Senate hearing of the GPR, senators also emphasised that 'military leaders [in Bulgaria and Romania] [...] offered things that the Europeans never did, the Western Europeans' (US Senate, 2004: 71). In this sense, a senior US official declared at an early stage of the negotiations that Romania was 'willing to open things up to us without significant restrictions' (Dunham, 2004). Thus, the 'places' envisaged by the access principle in the geopolitics of the GWOT were not the lily-pads themselves, but elsewhere.

But in a reversal of the transitional non-specificity of the GPR, to their hosts the bases demonstrated the significance of Romania as a 'geopolitical area of strategic importance' (NSSR, 2007: 29), as well as America's commitment to Romania. As a consequence, the GPR appeared both visionary and pragmatic in its recognition of Romania's 'geostrategic capacity', which had only become more relevant in the context of the GWOT (Cotidianul, 2001). In the local heteroglossic reading of the GWOT, the lily-pads were thus taken as the ultimate vindication of local geopolitics: a peremptory, indisputable proof of Romania's geostrategic worth (Moldovan et al., 2009: 12; Popa, 2005: 32).

Yet it was not only the geopolitics of the GWOT that was undermined in this profession of geopolitical self-worth; Romania's geopolitical identity was also denied at the very moment it was asserted. From the start, the status of a lily-pad had been defined by the 
contradiction between the need for maximum flexibility of deployment and the long-term commitment necessary for effective security cooperation with the host states (O'Hanlon, 2008: 6). From the perspective of the architects of the GPR, the lily-pads were the antithesis of the geostrategic apotheosis their Romanian hosts constantly imagined them to be. As former SACEUR General James L. Jones put it, 'we could use [a base] for six months, turn off the lights, and go to another base if we need to' (Isenberg, 2004: 2). In other words, the lily-pads that maximized access and flexibility were useful because they were disposable; paradoxically, the perfect lily-pad was not one that was geostrategically important, but one that did not matter at all.

In perfect alignment with the seam geometry of the GPR, Prime Minister Năstase argued in front of a US audience in 2003 that the Romanian lily-pads would constitute 'an excellent platform for various regions' (Fuller, 2003). Critics of NSSR 2007 later noted the fracture between the access logic of the GWOT and Romania's geopolitical identity, arguing that 'Romania defines itself and adopts the identity of a [...] space of transition' (IOS, 2006: 8, emphasis added). Embracing the identity of a lily-pad thus meant cancelling la pièce de résistance of Romania's archetypical representation of itself in geopolitical terms, because the significance of its oxn location was completely lost in the GPR's 'logic of global geography' (Bloomfield, 2006: 50).

Furthermore, the historical foundations of the two geopolitical visions were in constant tension, oscillating between self- and mutual subversion. On the one hand, Romania's geopolitical exceptionalism suffers from a familiar paradox. While the history of Romania, Europe, and geopolitics itself are taken as proof of Romania's geopolitical significance, its exceptionalism is considered beyond the caprice of history, changing political landscapes, or new policy agendas. On the other hand, this geopolitical mythology, painstakingly sourced in Romanian history, was incompatible with the geopolitics of the GWOT precisely because of the historical prejudice it was built upon. No myths, memories or histories could be fit into the geopolitics of the GWOT because the GWOT had no history, premised as it was on its own unprecedented nature, which was the ultimate source of its exceptionality and legitimacy.

Thus, the local inscription of the GWOT was inescapably paradoxical: its geopolitics was simultaneously embraced and negated in the name of a local geopolitics that was simultaneously celebrated and abjured in the negation as well as in the embrace of the hegemonic narrative. The heteroglossia inherent in the scripting on the local palimpsest generated a perpetual dissonance which turned upon both voices, sabotaging their selfassured geopolitical logic only to demand renewed enunciations in an unchanged register. 


\section{CONCLUSION}

What significance do the tensions, collusions and contradictions highlighted in Romania's case have for a grounded-contextual critical geopolitics? Three inter-related issues stand out. The first is that this particular context illustrates once more the 'palimpsestuous' nature and irreducible heteroglossia of geopolitical knowledge. As we have seen, only in a monoglossic reading of the geopolitics of the GWOT it would appear that it was unquestioningly 'imported' and 'lauded', as Agnew suggested (2007: 145). An understanding of geopolitics as palimpsest helps historicise and nuance the understanding of practices of import, acceptance and resistance alike.

The second issue concerns the fate of local geopolitics beyond the moment of encounter with hegemonic geopolitics. Ten years after the lily-pads agreement, Romania's sedimented geopolitics seems intact. Its exceptionalist bearings have not been uprooted, and it has survived the waning of the military engagements of the GWOT in Iraq and Afghanistan, the areas which the lily-pads were designed to enable transit to. Furthermore, the disappearance of the lily-pads from the headlines did not prompt any geopolitical soulsearching. Instead, their role in Romanian geopolitical lore was taken by a new base, the site for the Aegis-Ashore component of the European phased-adaptive approach to missile defence (EPAA) of the US and NATO. Romania was again an early and enthusiastic participant to this project (BBC, 2010; Marinaş, 2010); the agreement to host the missile site was signed on 13 September 2011, and came into force on 23 December 2011 after ratification by the Romanian Parliament (RParl, 2011). It would be the task of a different article to analyse the geopolitics of US missile defence, but there are signs that its logistical blueprint has replaced the reliance on short-term disposable bases with a focus on ultramobility through long term commitment to partners in familiar regional frames (US DoD, 2010a, b). Despite these differences, Romania's participation in the EPAA and the GPR has been signified geopolitically in the exact same terms. Romania's geopolitical importance was seen to have 'reached maximum' through its participation to the missile shield (Foreign Minister Cristian Diaconescu, in Popescu and Dobreanu, 2011), which constituted yet another spectacular recognition of Romania's 'geostrategic position' (RMFA, 2013: 4). In short, local geopolitical palimpsests turn out to be significantly more resilient than it is usually assumed.

This brings us to the third and final issue, regarding the normative implications of such geopolitical intersections. The Romanian context gives pause to the belief in the 'moral authority of the view from below', which as shown at the start, is intrinsic to the mandate of subaltern geopolitics in particular, and critical geopolitics more generally 
(Sharp, 2011: 304). Even if Romania's role in the GPR placed it in a subaltern or marginal position, Romania is certainly not seen, at least in local official or media discourse, as a 'victim of US geopolitics' (Ibid.). And even if it is possible to argue that its reception in Romania destabilised and subverted the geopolitics of the GWOT, this subversion was the product of a contradictory celebration, rather than a deliberate strategy of resistance. Not only this, but whatever destabilisation of the hegemonic geopolitics of the GWOT took place, it happened from the perspective of a different kind of hegemonic geopolitics, more Mackinderian than Rumsfeldian in flavour, although equally heteroglossic. So if anything, it should fall to a critically grounded analysis to denounce the geopolitics underpinning this 'view from below', whose claim for moral authority is at best tenuous. This is not to argue that critical geopolitics necessarily fails its normative mission in this case, but rather, that this mission is clearly dependent on, and would be enhanced by, contextual sensitivity.

ACKNOWLEDGEMENTS: This article draws on research conducted during a ESRC-SSRC Collaborative Visiting Fellowship at the Paul H. Nitze School of Advanced International Studies, Johns Hopkins University, Washington D.C., with support from the Centre for East European Language Based Area Studies (CEELBAS, UK). Alan Ingram and Ian Klinke have offered much needed comments and encouragement on earlier drafts. I am grateful to Lavinia Ochea and Gabriel Şopandă for their wonderful hospitality in Washington, and forever in debt to Olivia Toderean and Răduţa Matache for their long term support in completing this project.

\section{REFERENCES}

Actmedia (2015). Ion Iliescu for Der Spiegel: I approved CIA request for location in Romania. Actmedia Romanian News Agency, 24 April 2015, at http:/bit.ly/1HlqeDD (accessed 25 April 2015).

Agnew, J. (2007). Know-Where: Geographies of Knowledge of World Politics. International Political Sociology 1: 138-148.

Amoore, L. (2009). AlgorithmicWar: Everyday Geographies of the War on Terror. Alternatives 41(1): 4969.

Anderson, J.R. (2003). Transforming EUCOM, Part 2: Opportunities in Eastern Europe. Stars and Stripes European edition, 16 June 2003.

Barthes, R. (1973). Mythologies. New York: The Noonday Press.

Băsescu, T (2005). Black Sea Region: Promoting Freedom, Democracy and Regional Stability. Speech at the Council on Foreign Relations, 10 March 2005. 
Bakhtin, M.M. (1981). The Dialogic Imagination: Four Essays. Edited by Michael Holquist, translated by Caryl Emerson and Michael Holquist. Austin: University of Texas Press.

Bassin, M. and Aksenov, K. (2006) Mackinder and the Heartland Theory in Post-Soviet Geopolitical Discourse. Geopolitics 11(1): 99-118.

BBC (2003). US Eyes Romania for Bases. BBC News, 7 July 2003.

BBC (2005). Rice Signs US-Romania Bases Deal. BBC News, 6 December 2005.

BBC (2010). Romania 'To Host Missile Shield'. BBC News, 4 February 2010.

BBC Ro (2007). Oficialii români incriminaţi resping ferm acuzaţiile. BBC Romanian, 8 June 2007.

Bialasiewicz, L., Campbell, D., Elden, S., Graham, S., Jeffrey, A., Williams, A.J. (2007). Performing Security: The Imaginative Geographies of Current US Strategy. Political Geography 26(4): 405422.

Bloomfield, L.P. Jr. (2006). Politics and Diplomacy of the Global Defense Posture Review. In Lord, Carnes (ed.) Reposturing the Force: U.S. Overseas Presence in the Twenty-first Century. Naval War College Newport Papers 26 (Newport, RI: Naval War College Press), pp. 49-64.

Bowd, G. and Clayton, D. (2015) Emmanuel de Martonne and the Wartime Defence of Greater Romania: Circle, Set Square and Spine. Journal of Historical Geography 47: 50-63.

Braun, M. (2007-8). Indelible Ink of the Palimpsest: Language, Myth and Narrative in H.D.'s Trilogy. FACS 10: 1-28.

Brucan, S. (2005). Henry Kissinger şi politica externă a României. Revista 22, 795.

Calder, K.E. (2007). Embattled Garrisons: Comparative Base Politics and American Globalism. Princeton, NJ: Princeton University Press.

Campbell, K.M. and Johnson Ward, C. (2003). New Battle Stations? Foreign Affairs 82(5): 95-103.

CEU (2002). Draft Council Conclusions on the International Criminal Court. Council of the European Union, Brussels, 30 September 2002.

Cioculescu, S,. (2009) The Rebirth of Geopolitics in Post-Communist Romania: Ideas, Role and Collective Imaginary. Romanian Political Science Review 9(1): 119-151.

Ciută, F. (2007). Narratives of Security: Strategy and Identity in the European Context. In Mole, Richard (ed.) Discursive Constructions of Identity in European Politics (London: Palgrave), pp. 190207.

Ciută, F. (2008). Region? Why Region? Security, Hermeneutics, and the Making of the Black Sea Region. Geopolitics 13(1): 120-147.

Ciută, F. (2009). Security and the Problem of Context. A Hermeneutical Critique of Securitization Theory. Review of International Studies 35(2): 301-326.

Coleman, M. (2003). The Naming of 'Terrorism' and Evil 'Outlaws': Geopolitical Place-Making after 11 September. Geopolitics 8(3): 87-104.

Combat Films (2005). Launch Pads to Lily Pads (Combat Films/KBYU, 2005), at http://bit.ly/1n2Z4CW (accessed 2 September 2010). 
Constantinescu, E. (1997). The Security of Central Europe. Address at the $14^{\text {th }}$ NATO Workshop on Political-Military Decision-Making, Prague. http://www.csdr.org/97Book (accessed 7 March 2006 .

Cooley, A. (2005). Base Politics. Foreign Affairs 84(6): 1-14.

Cooley, A. (2007). U.S. Bases and Democratization in Central Asia. Orbis 52(1): 65-90.

Coon, C. (2008). Military Scales Back Romania Rotation Plans. Stars and Stripes European edition, 21 February 2008.

Cotidianul (2001) Poziția României, mai interesantă pentru NATO. Cotidianul, 29 September 2001.

Cotoi, C. (2000) Primordialism Cultural şi Geopolitică Românească. Bucharest: Mica Valahie.

Crang, M. (1996). Envisioning Urban Histories: Bristol as Palimpsest, Postcards, and Snapshots. Environment and Planning A 28(3): 429-452.

Critchlow, R.D. (2005). U.S. Military Overseas Basing: New Developments and Oversight Issues for Congress. Congressional Research Service Report, 31 October 2005.

Dahlman, C. and Ó Tuathail, G. (2005) Broken Bosnia: The Localized Geopolitics of Displacement and Return in Two Bosnian Places. Annals of the Association of American Geographers 95(3): $644-$ 662.

Dalby, S. (2003). Calling 911: Geopolitics, Security and America's New War. Geopolitics 8(3): 61-86.

Dalby, S. (2007). Regions, Strategies and Empire in the Global War on Terror. Geopolitics 12(4): 586606.

Dalby, S. (2009). Geopolitics, the Revolution in Military Affairs and the Bush Doctrine. International Politics 46(2/3): 234-252.

Davis, S. (2011). The US Military Base Network and Contemporary Colonialism: Power Projection, Resistance and the Quest for Operational Unilateralism. Political Geography 30(4): 215-224.

DNSSR (2006). Draft version (I) of the National Security Strategy of Romania.

Diac, M. (2015). Statele Unite pot trimite soldați în România în număr nelimitat. România Liberă 1 April 2015.

Didă, D. (2010a) Chestiuni punctuale în geopolitica românească interbelică. Etnosfera 3: 25-38.

Didă, D. (2010b) Orientări şi curente în geopolitica românească. Geopolitica, ştiinţa integralității teritoriale româneşti. Etnosfera 4: 30-37.

Dobrescu, P. (2003) Geopolitica. Bucharest: Comunicare.ro.

Dunham, W. (2004). Rumsfeld Views Possible U.S. Bases in Romania. Reuters, 11 October 2004.

EP (2007). Report for the European Parliament on the Alleged Use of European Countries by the CIA for the Transportation and Illegal Detention of Prisoners, 2006/2200(INI).

Folch-Serra, M. (1990). Place, Voice, Space: Mikhail Bakhtin's Dialogical Landscape. Environment and Planning D: Society and Space 8(3): 255-274.

Fuller, T. (2003). Romania Dangles Use of a Sea Base to Woo US. International Herald Tribune 18 June 2003. 
Garamone, J. (2004a). Officials Discuss Global Posture Process. American Forces Press Service,

Washington, 9 June 2004. http://www.defenselink.mil (accessed 24 February 2009).

Garamone, J. (2004b). Defense Details Global Posture Realignment Process. American Forces Press Service, Washington, 23 June 2004 at http://1.usa.gov/1s4kwNh (accessed 30 August 2010).

Geertz, C. (2000) Local Knowledge: Further Essays in Interpretive Anthropology, $3^{\text {rd }}$ ed. New York: Basic Books.

Genette, G. (1997). Palimpsests: Literature in the Second Degree. Trans. Channa Newman and Claude

Doubinsky. Lincoln, NB: University of Nebraska Press.

GMF (2005). TAF Cooley Discusses Politics of U.S. Bases Abroad. German Marshall Fund of the United States, Washington D.C., 17 November 2005.

Gregory, D. (1995). Imaginative Geographies. Progress in Human Geography 19(4): 447-485.

Gregory, D. (2004) The Colonial Present. Oxford: Blackwell.

Henry, R. (2006). Transforming the U.S. Global Defense Posture. In Lord, Carnes (ed.) Reposturing the Force: U.S. Overseas Presence in the Twenty-first Century. Naval War College Newport Papers 26 (Newport, RI: Naval War College Press), pp. 33-48.

ICC (1998). Rome Statute of the International Criminal Court.

Iliescu, I. (1994). Inaugural Speech at the Crans-Montana Economic Forum. 21 April 1994. http://bit.ly/1rPmFyS (Accessed 10 April 2014).

Iliescu, I. (2003). Integrare şi Globalizare. Bucharest: Nemira.

Ingram, A. (2009). Art and the Geopolitical: Remapping Security at Green Zone/Red Zone. In Ingram, Alan and Dodds, Klaus (eds.) Spaces of Security and Insecurity: Geographies of the War on Terror (Farnham: Ashgate), pp. 257-277.

Ingram, A. and Dodds, K. (2009). Spaces of Security and Insecurity: Geographies of the War on Terror. In Ingram, Alan and Dodds, Klaus (eds.) Spaces of Security and Insecurity: Geographies of the War on Terror (Farnham: Ashgate), pp. 1-20.

Institutul PRO (2006). O strategie cât un program de guvernare: analiza proiectului Strategiei de Securitate Naţională a României. Institutul PRO, 8 March 2006. http://www.infopolitic.ro (accessed 21 March 2006).

IOŞ (2006). Analiza Strategiei de Securitate Naţională a României. Institutul Ovidiu Şincai, Bucharest. http://bit.ly/1kmt7Lq (accessed 15 February 2014).

IPP (2005). Percepţia opiniei publice din România asupra politicii externe şi a relaţiilor internaţionale. Bucharest: Institutul pentru Politici Publice.

Isenberg, D. (2004). The U.S. Global Posture Review: Reshaping America's Global Military Footprint. BASIC Occasional Paper On International Security Policy. http://bit.ly/1oL3TGe (accessed 1 December 2008).

ISN (2005). US Troops Heading to Bulgaria, Romania. ISN Security Watch, 26 October 2005. 
Jones, A. \& Clark, J. (2012). Practicing Geographical Uniqueness: The Geopolitics of Prenegotiation and Icelandic Accession to the European Union. Annals of the Association of American Geographers 103(6): 1437-1451.

Kearns, G. (2006). Naturalising Empire: Echoes of Mackinder for the Next American Century? Geopolitics 11(1): 74-98.

Kennedy-Pipe, C. and Rengger, N. (2006). Apocalypse Now? Continuities or Disjunctions in World Politics after 9/11. International Affairs 82(3): 539-52.

Kuus, M. (2007). Geopolitics Reframed. Security and Identity in Europe's Eastern Enlargement. London: Palgrave.

Kuus, M. (2013). Places of Lower Rank: Margins in Conversations. Political Geography 37: 30-32.

Lefter, I.B. (2005). Axa Continuităţii. Ziua, 8 December 2005.

Mackinder, H.J. (1919). Democratic Ideals and Reality. A Study in the Politics of Reconstruction. New York: Henry Holt \& Co.

Marcuse, H. (1964). One-Dimensional Man. Studies in the Ideology of Advanced Industrial Society. London: Routledge.

Marinaş, R. (2010). Romania Backs U.S. Plan to Host Anti-Missile Shield. Reuters, 4 February 2010.

Martinescu, D. (2009). Şomeri şi sărăcie în paradisul bazelor americane din Dobrogea. România Liberă, 28 May 2009.

Massey, D. (2005). For Space. London: SAGE.

Mediafax (2008). Romania-US Bilateral Immunity Agreement not in Effect. 9 May 2008.

Mitin, I. (2010). Palimpsest. In Warf, Barney (ed.) Encyclopedia of Geography (Thousand Oaks, CA: SAGE), pp. 2111-2112.

Moldovan, D., Pantev, P., and Rhodes, M. (2009). Joint Task Force East and Shared Military Basing in Romania and Bulgaria. George C. Marshall European Center for Security Studies Occasional Paper 21.

Morris, P. (1994) The Bakhtin Reader: Selected Writings of Bakhtin, Medvedes and Voloshinov. London: Arnold.

Munteanu, M. (2005). Ungureanu şi Bazele Marelui Licurici. Ziua, 6 December 2005.

Nazare, V. (2005). Geopolitică şi realism politic la Marea Neagră. GeoPolitica: Revistă de Geografie Politică, GeoPolitică şi GeoStrategie 3(14-15): 67-84.

Noonan, M.P. (2004). Reform Overdue: the Geopolitics of American Redeployment. Foreign Policy Research Institute E-Note. http://bit.ly/1qmGLvO (accessed 16 February 2014).

NSSR (2007). The National Security Strategy of Romania.

Ó Tuathail, G. (2004). Geopolitical Structures and Cultures: Towards Conceptual Clarity in the Critical Studies of Geopolitics. In Tchantouridze, Lasha (ed.) Geopolitics: Global Problems and Regional Concerns (Winnipeg: Centre for Defence Studies), pp. 75-102.

Ó Tuathail, G. (2008). Book Forum: Derek Gregory's The Colonial Present. Political Geography 27(3): 339-370. 
Ó Tuathail, G. (2010). Localizing Geopolitics: Disaggregating Violence and Return in Conflict Regions. Political Geography 29(5): 256-265.

O'Hanlon, M. (2008). Unfinished Business: U.S. Overseas Military Presence in the 21st Century, Center for a New American Security. http://bit.ly/1qmGFV9 (accessed 24 February 2009).

OBC (2005). Commission on Review of Overseas Military Facility Structure of the United States: Report to the President and US Congress. http://bit.ly/1AyG8WR (accessed 17 February 2014). Orescu, Ş. (2005). Vin americanii! În ce măsură trebuie să ne bucurăm? Ziua, 8 December 2005. Oza, R. (2007). Contrapuntal Geographies of Threat and Security: The United States, India, and Israel. Ensironment and Planning D: Society and Space 25(1): 9-32.

PACE (2006a). Alleged Secret Detentions and Unlawful Inter-State Transfers Involving Council of Europe Member States, $1^{\text {st }}$ Report. Parliamentary Assembly of the Council of Europe, Doc. 10957.

PACE (2006b). Alleged Secret Detentions and Unlawful Inter-State Transfers Involving Council of Europe Member States, Draft Report - Part II (Explanatory memorandum). Parliamentary Assembly of the Council of Europe, AS/Jur (2006) 16.

PACE (2007). Secret Detentions and Illegal Transfers of Detainees Involsing Council of Europe Member States, $2^{\text {nd }}$ Report. Parliamentary Assembly of the Council of Europe, Doc. 11302 rev.

Pantazi, C. and Cozmei, V. (2015) Prezenţa militară americană în România: câţi soldaţi şi ce armament au trimis SUA pentru a asigura securitatea României faţă de ameninţările Rusiei. Hotnews.ro, 25 June 2015. http://bit.ly/1HDMpUo (accessed 26 June 2015).

Paşcu, I.M. (2002). Statement by the Romanian Minister of National Defence at the $38^{\text {th }}$ Conference on Security Policy. Munich, 3 February 2002.

Perescu, A. (2005). Baze militare americane în România. BBC Romanian, 6 Decembrie 2005.

Pleşu, A. (1998). The Indivisibility of Security and the Necessity of Continuation of the NATO Enlargement Process. Address at the Nobel Institute, Oslo, 12 January 1998. http:/bit.ly/1s30xPT (accessed 14 march 2010).

Pintescu, F. (2005). Geopolitica şi geostrategia pontică românească între tradiţie şi actualitate. GeoPolitica: Revistă de Geografie Politică, GeoPolitică şi GeoStrategie 3(14-15): 85-90.

Popa, V. (2005). Redislocarea bazelor militare ale SUA în Europa de Est-România. Bucharest: Editura Universităţii Naţionale de Apărare.

Popescu, A. and Dobreanu, C. (2011). La ce-i foloseşte României scut antirachetă lângă Caracal. România Liberă, 3 May 2011.

Posea, G. (1994) Geopolitica şi geopolitică românească. In Emandi, E.I., Buzatu, G. and Cucu, V.S. (eds.) Geopolitica, vol. I (Iaşi: Glasul Bucovinei), pp. 347-348.

RMFA (2005). Semnarea Acordului româno-american privind activităţile forţelor Statelor Unite staţionate pe teritoriul României. http://www.mae.ro (accessed 14 march 2010).

RMFA (2013). Annotated Text of the Agreement between Romania and the USA Regarding the Deployment of the US Missile Defence System in Romania. Romanian Ministry of Foreign Affairs, at http://www.mae.ro/print/1517 (accessed 14 march 2010). 
RParl (2001). Hotărârea 21 din 19 septembrie 2001 privind participarea României, împreună cu statele membre ale NATO, la acţiunile de combatere a terorismului internațional. Monitorul Oficial 589, 20 September 2001.

RParl (2006a). Acordul din 6 decembrie 2005 între România şi Statele Unite ale Americii privind activităţile forțelor Statelor Unite staţionate pe teritoriul României. Monitorul Oficial 585, 6 July 2006.

RParl (2006b). Legea 268 din 29 iunie 2006 (Legea 268/2006) pentru ratificarea Acordului dintre România şi Statele Unite ale Americii privind activităţile forţelor Statelor Unite staţionate pe teritoriul României, semnat la Bucureşti la 6 decembrie 2005. Monitorul Oficial 585, 6 July 2006.

RParl (2007). Transcript of the Joint Session of the Romanian Senate and Chamber of Deputies, 2 May 2007. http://www.cdep.ro (accessed 14 March 2010).

RParl (2011). Legea 290/2011 pentru ratificarea Acordului dintre România şi Statele Unite ale Americii privind amplasarea sistemului de apărare împotriva rachetelor balistice al Statelor Unite in Romania. Monitorul Oficial 910, 20 December 2011.

Rumsfeld, D. (2004a). Positioning America's Forces for the 21st Century. Global Posture Editorial. http://1.usa.gov/1nTI7kt (accessed 16 February 2014).

Rumsfeld, D. (2004b). Global Posture. Testimony to the Senate Armed Service Committee. http://bit.ly/1s30F1X (accessed 16 February 2014).

Ryan, M. (2011). 'War in Countries We Are Not At War With': The 'War on Terror' on the Periphery from Bush to Obama. International Politics 48(2/3): 364-389.

Săgeată, R. (2011). Direcții şi tendinţe în geopolitica românească din perioada interbelică. Analele Asociaţiei Profesionale a Geografilor din România 2(2): 5-15.

Said, E.W. (1994). Culture and Imperialism. London: Vintage.

Schrader, E. (2003). U.S. Expedites Reshuffling of Europe Troops. Los Angeles Times, 1 May 2003.

Sharp, J. (2011). A Subaltern Critical Geopolitics of the War on Terror: Postcolonial Security in Tanzania. Geoforum 42(3): 297-305.

Sharp, J. (2013) Geopolitics at the Margins? Reconsidering Genealogies of Critical Geopolitics. Political Geography 37: 20-29.

Shimkus, J. (2006). Changes in US Forward Deployment and its Effects on Europe. NATO Parliamentary Assembly Report 169 DSCTC 06 E.

Sidaway, J.D. (2010). 'One Island, One Team, One Mission’: Geopolitics, Sovereignty, 'Race’ and Rendition. Geopolitics 15(4): 667-683.

Sidaway, J.D. (2012). Subaltern Geopolitics: Libya in the Mirror of Europe. The Geographical Journal $178(4): 296-301$.

Simileanu, V. and Săgeată, R. (2009) Geopolitica României. Bucharest: Top Form.

Stan, I. (2007). Strategia portocalie a insecurităţii naționale. Intervention in the Romanian Chamber of Deputies, 23 October 2007. http://bit.ly/28J0abd (accessed 20 June 2016). 
Stoicescu, M. (2008). Liminality in International Relations: A Comparative Analysis of Discursive

Articulations in the Geopolitical Visions of Romania, Turkey, and Ukraine. Doctoral dissertation,

Graduate Institute of International and Development Studies, Geneva.

Strategikon (2006). Roundtable: Beyond the Black Sea. http://bit.ly/1s4jLny (accessed 10 June 2014).

Sullivan, K. (2006). Romanians Eager for Long-Awaited Arrival of the Yanks. Washington Post A10, 6 February 2006.

US DoD (2003). Under Secretary Feith Press Conference with the Romanian Minister of National Defense. 10 December 2003. http://1.usa.gov/WN6ipT (accessed 16 February 2014).

US DoD (2004a). Strengthening U.S. Global Defense Posture: Report to Congress..

US DoD (2004b). Background Briefing on Global Posture Review. http://1.usa.gov/1obnbj6 (accessed 16 February 2014).

US DoD (2010a). Quadrennial Defense Review Report.

US DoD (2010b). Ballistic Missile Defense Review Report.

US JCS (2006). National Military Strategic Plan for the War on Terrorism. Joint Chiefs of Staff, 1 February 2006, http://1.usa.gov/WN6jtK (accessed 30 August 2010).

US Senate (2004). The Global Posture Review of United States Military Forces Stationed Overseas.

Hearing before the Committee on Armed Services, US Senate, 23 September 2004.

http://bit.ly/1ldkb5O (accessed 23 August 2013).

Vilnius 10 (2003). Statement of the Vilnius Group Countries on Iraq. 5 February 2003.

Vine, D. (2009). Island of Shame: The Secret History of the US Military Base on Diego Garcia (Princeton, NJ: Princeton University Press).

Vine, D. (2012). U.S. Empire of Bases Grows. http://www.tomdispatch.com/blog/175568/.

Warf, B. (1997) The Geopolitics/Geoeconomics of Military Base Closures in the USA. Political Geography 16(7): 541-563.

White House (2002). National Security Strategy of the United States of America.

Woodward, R. (2004). Military Geographies. Oxford: Blackwell.

Woon, C.Y. (2011). Undoing Violence, Unbounding Precarity: Beyond the Frames of Terror in the Philippines. Geoforum 42(3): 285-296.

Ziua (2005). Bazele militare americane vin in România. Ziua, 7 May 2005. 
${ }^{1}$ A review of the extensive critical geopolitical literature would far exceed the space available in this article, so the argument will work with the relatively safe assumption that the readers of Political Geography are familiar with its key tenets and its normative tenor more specifically.

${ }^{2}$ Even an abridged review of the literature published in Romania on this topic would take considerable space. The open-access journal GeoPolitica: Revistă de Geografie Politică, GeoPolitică şi

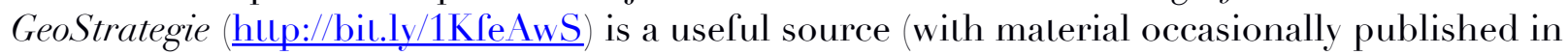
English) which illustrates the tropes of Romanian geopolitics, as well as its constant mapping onto current official state discourse on foreign and security policy. 